\title{
The Destruction of Statehood and the Color Revolutions under Russian International Law Doctrine
}

\author{
Tero Lundstedt ${ }^{1}$ \\ DOI: $10.21827 /$ GroJIL.8.2.228-243 \\ Keywords: \\ DESTRUCTION OF STATEHOOD; COLOR REVOLUTIONS; CRIMEA
}

\begin{abstract}
Has Russian international law doctrine changed in relation to the post-Soviet states since the annexation of Crimea? This paper analyses two interdependent concepts of the contemporary Russian international law doctrine - the 'color revolutions' and the 'destruction of statehood' - in the context of geopolitical competition over the post-Soviet space. In brief, the term color revolution is used by Russia to describe events that it categorizes as illegal regime-changes used to remove pro-Russian politicians from power under the guise of democracy. In the same context, Russia has developed another key concept, i.e. the 'destruction of statehood'. First referred to in 2008, it has since 2014 become a more encompassing and innovative legal doctrine to counter color revolutions in Russia's neighboring states. Under this doctrine, Russia reserves a right to 'un-recognize' a target state if it categorizes the situation as an illegal regime change that has destroyed the target's statehood. Controversially, this results in Russia no longer being bound by its treaty obligations with this state. Especially since 2014, Russia has developed political and legal tools in multilateral documents to counter future color revolutions. While it has been unable to convince the international community to accept its new interpretations, it has been more successful within its closest allies in the Collective Security Treaty Organization (CSTO) and, to a lesser extent, in the Commonwealth of Independent States (CIS). This may have significant political consequences in the future.
\end{abstract}

\section{Background: 'Near Abroad' and the First Wave of 'Color Revolutions', 1992-2010}

In essence, the 'destruction of statehood' doctrine is a way to justify Russian interference with the internal affairs of its post-Soviet neighbor states, which is otherwise in clear violation of the international law doctrine on non-interference. In order to explain this phenomenon, I first establish the rationale behind the Russian perception of its special rights in these states by accounting for the post-Cold War security environment in Europe, which partially explains Russia's negative attitude towards the enlargement of the North Atlantic Treaty Organization (NATO) and the European Union (EU). Following this, I analyze how ex-Soviet states have

\footnotetext{
1 Tero Lundstedt is a PhD candidate from the University of Helsinki, Erik Castrén Institute of International Law and Human Rights. He did his LL.M at the same University, with master's thesis about the legality of Kosovo's independence in 2008. His PhD work - which was defended on 1 August 2020 - focuses on the territorial disputes caused by the socialist federal dissolutions of the USSR and Yugoslavia in the early 1990s, especially by analysing the legal principle of uti possidetis juris. His other publication work encompasses Russian international law doctrine and foreign policy. Tero would like to thank KU University Leuven and its Centre of Global Governance Studies, and especially Prof. Dr. Jan Wouters and Dr. Axel Marx for giving him a possibility to present the first version of this article in the form of a presentation in the Centre of the Global Governance Studies in September 2018.

This work is licensed under the Creative Commons Attribution-NonCommercial-NoDerivatives 4.0 International License. To view a copy of this license, visit http://creativecommons.org/licenses/by-nc-nd/4.0/.
} 
become 'near abroad' states, and, subsequently, why the 'color revolutions' are not seen as their internal affairs.

\section{A. The Post-Cold War Security Environment in Europe}

In 1990, the Cold War ended with the German reunification and the Warsaw Pact's slow dissolving. The Union of Soviet Socialist Republics (USSR) was worried that the Warsaw Pact countries might seek to join NATO and there were series of high-level discussions between the United States (US) Secretary of State James Baker and the President of the USSR Mikhail Gorbachev. While Gorbachev was unable to secure a pledge that NATO would not take in these countries, he did receive assurances that NATO would revise its strategy and position within a transformed Europe. ${ }^{2}$

The end of the Cold War called for a symbolic peace treaty, and on 21 November 1990, the Charter of Paris for a New Europe was signed by 32 European states, the US and Canada under the auspices of the Conference on Security and Co-operation in Europe (CSCE). In a key phrase, the Charter proclaimed that ' $[w]$ ith the ending of the division of Europe, we will strive for a new quality in our security relations while fully respecting each other's freedom of choice in that respect. Security is indivisible and the security of every participating state is inseparably linked to that of all the others'. ${ }^{3}$

In 1994, the CSCE's Budapest Document stated that the participants 'will not strengthen their security at the expense of the security of other States [...]. Each will respect the rights of all others in this regard'. In 1996, the now renamed Organization for Security and Co-operation in Europe (OSCE) stated in a Lisbon Declaration that ' $[w]$ ithin the OSCE, no State, organization or grouping can [...] regard any part of the region as its sphere of influence'. ${ }^{4}$

In 1997, NATO invited the former Warsaw Pact countries of Poland, the Czech Republic and Hungary to join NATO, ${ }^{5}$ but attempted to decrease Russian threat perceptions by signing a Founding Act on their mutual relations. It stated that NATO aimed to create 'in Europe a common space of security and stability, without dividing lines or spheres of influence limiting the sovereignty of any state', and that '[p]rovisions of this Act do not provide NATO or Russia, in any way, with a right of veto over the actions of the other'. ${ }^{6}$ Following that, in 1999, OSCE produced a Charter for European Security, which gave an expanded definition of security relations in Europe: 'We reaffirm the inherent right of each and every participating State to be free to choose or change its security arrangements, including treaties of alliance, as they evolve [...]. Each participating State will respect the rights of all others in these regards. They will not strengthen their security at the expense of the security of other States'?

2 John Ikenberry, After Victory: Institutions, Strategic Restraint, and the Rebuilding of Order After Major Wars (Princeton University Press 2001) 230.

3 Commission on Security and Cooperation in Europe (CSCE) 'The Charter of Paris for a New Europe' (21 November 1991) 30 ILM 1990 (The Charter of Paris).

4 CSCE 'Budapest Document: Towards a Genuine Partnership in a New Era' (21 December 1994).

5 Madrid Declaration on Euro-Atlantic Security and Cooperation [1997] OJ 1 338/1.

6 Founding Act on Mutual Relations, Cooperation and Security between NATO and the Russian Federation [1997] OJ 1 138/166.

7 CSCE Charter for European Security (adopted on 18 November 1999, entered into force on 19 November 1999), art 8. 
Therewith, the OSCE's definitions can be read as both giving all the participating states freedom to choose their security alliances, while denying them the right to do so at the expense of other states, as security is indivisible. These ambiguities proved to be detrimental to the security relations in Europe.

\section{B. The 'Near Abroad'}

The term 'near abroad' (ближнее зарубежье), used extensively in Russia since 1992 to refer to the former Soviet Socialist Republics (SSRs), summarises the main policy issue with Russia and most of its post-Soviet neighbors well. According to Bodie, 'Russia's political classes have difficulty viewing the republics on its periphery as fully sovereign entities; use of the term near abroad, in addition to qualifying their independence, signifies to the "far abroad" that Russia claims certain rights in the region that transcend traditional diplomatic conventions'. Trenin argues that '[f]or many in Russia, the new states are not yet quite states. Interestingly, Moscow's political relations with them are still managed by the Kremlin chief of staff, rather than the foreign minister' ${ }^{8}$

The Commonwealth of Independent States (CIS) was established on 21 December 1991 by 11 SSRs to accomplish a 'civilized divorce' of the USSR. It produced numerous treaties, especially on economic relations and security. ${ }^{9}$ Among them was the Collective Security Treaty in 1992. The signatory states promised not to join other military alliances, to increase their 'close and all-round allied relations in foreign policy', and to 'approve and coordinate their foreign policy positions on the international and regional security problems' ${ }^{10}$ All decisions under the Treaty had to be made by consensus, giving all the signatories a virtual veto.

Russia saw the CIS from the very beginning as a useful instrument to retain its influence over the post-Soviet space. In August 1992, the chairman of the Duma Foreign Affairs Committee suggested that Russia should include all the post-Soviet states in its 'sphere of influence'. ${ }^{11}$ The CIS Charter of 22 January 1993 obligated the signatories to build their relations with concern for the interests of each other and to coordinate their policy in the field of international security. ${ }^{12}$ In 1993, Foreign Minister Kozyrev asked the UN to recognise Russia's special responsibility for keeping the peace in the CIS area. The 1993 Foreign Policy Concept made relations with the CIS states a foreign policy priority and demanded that these relations have to be built on premises that they take Russian interests properly into account, especially by guaranteeing the rights of the Russian diaspora. ${ }^{13}$

8 William Safire, 'On Language: The Near Abroad' New York Times (22 May 1994) 16; and Dmitri Trenin, Post-Imperium: A Eurasian Story (Carnegie Endowment for International Peace 2011) 80.

9 Alma-Ata Declaration (adopted on 12 September 1978, entered into force 12 September 1978) 31 ILM 148; The term 'civilized divorce' has been used in the official CIS documents, Yulia Nikitina, 'Security Cooperation in the Post-Soviet Area within the Collective Security Treaty' (2013) ISPI Analysis No. 152, 2. Collective Security Treaty Organization (CSTO) Collective Security Treaty (adopted on 15 May 1992, entered into force 15 May 1992), Preamble, arts 1, 9 and 12; The original signatories were Armenia, Azerbaijan, Belarus, Georgia, Kazakhstan, Kyrgyzstan, Russia, Tajikistan and Uzbekistan.

11 Konstantin Eggert, 'Rossii v roli “evraziiskogo zhandarma”' (Izvestiia, 7 August 1992).

12 Charter of the Commonwealth of Independent States (adopted 22 January 1993, entered into force 22 January 1994) 58 UNTS 1819, arts 3 and 12.

13 Foreign Policy Concept of the Russian Federation (23 April 1993). 
In September 1995, a Russian presidential decree maintained that effective cooperation with the CIS is a factor that 'opposes the centrifugal tendencies in Russia itself'. Additionally, the main task of foreign policy was stated to be ensuring that the CIS states conduct friendly policy towards Russia, the leading force in the formation of interstate political and economic relations in the post-Soviet space. Finally, it communicated that while the integration in the CIS was not mandatory, it will be 'an important factor determining the scale of economic, political and military support from Russia'. ${ }^{14}$ This decree remains in force.

Since Vladimir Putin's accession, Russian rhetoric has changed from referring to a sphere of influence to that of interest. In August 1999, Prime Minister Putin stated that Russia 'has always had and still has legitimate zones of interest abroad in both the former Soviet lands and elsewhere'. In 2003, he referred to the CIS area as 'the sphere of our strategic interest'. ${ }^{15}$

To conclude, by the late 1990s Russia thought it had an understanding with NATO against eastern enlargement. In addition, Russia hoped to retain some influence in the former Warsaw Pact states and a significant influence over the CIS space, which it continued to consider as its sphere of interest. The problem that was already visible at this stage was the incompatibility of the Russian notion of its sphere of interest and the sovereignty of the states within this self-proclaimed sphere.

\section{NATO Enlargement, 1999-2004}

In 1999, the relations between Russia and the West began to worsen. In March, NATO used force against Serbia, due to the Serb policies in Kosovo. Russia was unable to stop the intervention, because NATO acted without UN Security Council approval. In April, Hungary, Poland and the Czech Republic became NATO members. NATO tried again to mitigate Russia's threat perceptions by a 2002 declaration 'NATO-Russia Relations: A New Quality' in which they reaffirmed that indivisibility of security. ${ }^{16}$ Additionally, Russia was granted more prominence by its admittance to the G7, the International Monetary Fund and the World Trade Organization. Nevertheless, Russia remained sceptical and the 1992 Collective Security Treaty was transformed into the Collective Security Treaty Organization (CSTO) in October 2002. ${ }^{17}$

The 2003 invasion of Iraq - again without UN Security Council's approval - derailed the relationship between Russia and the West further. It was interpreted in Moscow as marginalizing the Security Council, a permanent membership of which is central to Russia's self-image as a Great Power and which it had been so determined to retain after the dissolution of the USSR.

In 2004, the Eastern enlargements of NATO (by six states) and the EU (by ten states) took place, which for the first time welcomed former SSRs of the USSR (Estonia, Latvia and

14 'Russia's Strategic Course in its Relations with the States-Participants of the Commonwealth of Independent States' (14 September 1995) Presidential Decree, arts 1, 4 and 7; Translation by the Author. In addition, art 12 prohibited participation in any alliances directed against Russia.

15 Ijaz Ayman, 'Russia's Resurgence: Global-Regional Threat and Opportunities' [2016] 1((1-2)30) Journal of Current Affairs 30-33.

16 North Atlantic Treaty Organization, 'NATO-Russia Relations: A New Quality' (28 May 2002).

17 Charter of the Collective Security Treaty Organization (adopted on 7 October 2002, entered into force on 7 October, 2002). The Charter was signed by Armenia, Belarus, Kazakhstan, Kyrgyzstan, Russia and Tajikistan. 
Lithuania) as members. The problem that could not be overcome was that while NATO was willing to give Russia a place at the table to co-decide issues together, it was unwilling to give it a veto on enlargement. This would have been a confirmation of Russia's sphere of influence and a re-division of Europe along the Cold War lines.

In sum, Russia saw the 1999-2004 enlargements of the Western organizations as being directed against it, and the unilateral use of force decreased trust in the Western assurances of the opposite.

\section{The First Wave of Color Revolutions, 2003-2006}

Russian officials have used the term 'color revolution' since 2003. ${ }^{18}$ Just as with the NATO enlargement, the perception of color revolutions differs fundamentally between the West and Russia. For the former, they are legitimate democratic movements, an expression of the free will of peoples who should be free to choose their political and security alignments. Even a change of regime through extra-parliamentary means remains within the internal affairs of a state. International law does not prohibit revolutions; it only prohibits external states from organising or supporting such revolutions.

Russia focuses on the external actors. In this narrative, the color revolutions are driven by external influence, thereby violating the target state's sovereignty. It has been able to convince the Russian public that the West instigates color revolutions, which only brings economic and political chaos.

In 2003-2006, four color revolutions took place in the post-Soviet space, with three bringing down a pro-Russian government. In November 2003, a 'Rose Revolution' in Georgia brought pro-Western Mikheil Saakashvili into power. In 2004, Ukraine's ‘Orange Revolution' caused the pro-Russian Viktor Yanukovych to lose his presidency to pro-Western Viktor Yuschenko. In early 2005, President Putin commented that these permanent revolutions will 'plunge all the post-Soviet space into a series of never-ending conflicts, which will have extremely serious consequences'. In February 2005, he continued: 'My greatest concern is not that dramatic events are taking place there, but that they are going outside the framework of the existing legislation and constitution' ${ }^{19}$

In April 2005, a 'Tulip Revolution' took down Kyrgyzstan's President Askar Akayev, replaced by opposition's Kurmanbek Bakiyev. A revolution in Kyrgyzstan had been expected, and afterwards Russian scholars and politicians condemned it as a part of a systematic set of color revolutions. ${ }^{20}$ This seemed to be confirmed by President George W. Bush's proclamation of the formation of a special 'Active Response Corps' to advance democracy and freedom throughout the world. Bush called the democratic change in the former SSRs as

18 According to Defense Minister Sergei Shoigu's speech on 29 May 2014 at the Moscow Conference on International Security, the scheme of color revolutions had been used in Serbia, Libya, Syria, Ukraine and Venezuela.

19 Vladimir Putin, 'This Year Was Not an Easy One' (2005) 51(1) International Affairs 3.

20 The title 'Tulip Revolution' was already coined by Akayev in 2004; Vladimir Radyuhin, 'Moscow and Multipolarity' (30 December 2004) The Hindu 6. The revolution was widely categorised as a part of the colour revolution pattern, by, for example, Gleb Pavlovsky, Andrannik Migrainian, Stefanie Ortmann in Stefanie Ortmann, 'Diffusion as Discourse of Danger: Russian Self-Representations and the Framing of the Tulip Revolution' (2008) 27 Central Asian Survey 363, 369-373); and by the former Foreign Minister Igor Ivanov in Yulia Nikitina, 'The "Color Revolutions" and "Arab Spring" in Russian Official Discourse' (2014) 14 (1) Partnership for Peace Consortium of Defense Academies and Security Studies Institutes 87, 95. 
'only the beginning. We are seeing the rise of a new generation whose hearts burn for freedom - and they will have it'. The Secretary of the Russian Security Council Nikolai Patrushev responded in the Duma: 'Our opponents are steadily and persistently trying to weaken Russian influence in the CIS and the international arena as a whole. The latest events in Georgia, Ukraine and Kyrgyzstan unambiguously confirm this' ${ }^{21}$

Belarus' President Lukashenka feared he was next in line, commenting in February 2005 that the West thinks Belarus is ready for a color revolution. However, while there were significant protests after the 2006 elections, Lukashenka - aided by Moscow - was able to hold on to power in Minsk. ${ }^{22}$ A similar situation has developed since the August 2020 presidential elections that are widely believed to have been fraudulent.

\section{E. Kosovo and Georgia, 2008}

The Russia-West relations continued on an ever-worsening path. In the 2007 Munich Security Conference, Putin aired many of his grievances of the Western policies in the post-Soviet space. ${ }^{23} 2008$ began with the highly controversial Kosovo independence, followed in April by a summit where NATO pledged that Georgia and Ukraine would become members in the future. ${ }^{24}$ Putin took the occasion to warn Bush in the auspices of the Russia-NATO Council that Ukraine's entry into NATO might prompt Russia to encourage predominantly Russianinhabited regions to secede. ${ }^{25}$

Then came the August 2008 Georgian war. Afterwards, President Dmitry Medvedev reaffirmed the Russian sphere of interest in the region, and Foreign Minister Sergey Lavrov called the war a 'long-desired moment of truth' for Russia's relations with the West. ${ }^{26}$ Most importantly, in October 2008 Lavrov compared the Rose and Orange revolutions to the 1917 October Revolution and stated that this could be seen as creating a completely new state with which Russia would not have any binding agreements. ${ }^{27}$ This was the first official reference to the destruction of statehood formula.

Furthermore, the EU became a revisionist actor from the Russian perspective with the launch of the Eastern Partnership (EaP) Program in 2009, which promised Armenia, Azerbaijan, Belarus, Georgia, Moldova and Ukraine political and economic integration without guarantees for membership. Russia felt betrayed, as it was not consulted beforehand. Lavrov called the EaP an 'EU attempt to expand its "sphere of influence"', and 'to weaken

21 BBC News, 'US Pledges to Aid New Democracies' (BBC News, 19 May 2005) $<$ http://news.bbc.co.uk/2/hi/americas/4561145.stm $>$ accessed 7 December 2020; the second quote in Taras Kuzio, 'Soviet Conspiracy Theories and Political Culture in Ukraine: Understanding Viktor Yanukovych and the Party of Regions' (2011) 44(3) Communist and Post-Communist Studies 221, 223.

22 'Lukashenko says no to' (United Civil Partym, 24 February 2005) <https://web.archive.org/web/20050430223422/http://www.ucpb.org/eng/show1prel.shtml?no=1241>, accessed 7 December 2020; Thomas Ambrosio, 'The Political Success of Russia-Belarus Relations: Insulating Minsk from a Color Revolution' (2006) 14(3) Demokraizatsiya 407.

23 Speech at the Munich Conference on Security Policy (10 February 2007).

24 North Atlantic Treaty Organization Bucharest Summit Declaration [1985] OJ 2 342/19, para 23.

25 Mark Kramer, 'Russian Policy Toward the Commonwealth of Independent States: Recent Trends and Future Prospects' (2008) 55(6) Problems of Post-Communism 3, 9.

26 Valerie Pacer, Russian Foreign Policy under Dmitry Medvedev, 2008-2012 (Routledge 2016) 20.

27 'A Conversation with Sergey Lavrov' (The Council on Foreign Relations, 24 September 2008) < https://www.cfr.org/event/conversation-sergey-lavrov> accessed 7 December 2020. 
Russian influence in the post-Soviet space and offer a different development model to the former Soviet Republics'. ${ }^{28}$

\section{F. 'Reset', 2009}

2009 was a time for new beginnings in the Russia-West relations. In March, Russia did not strongly oppose Albania and Croatia joining NATO. The OSCE started the Corfu Process, with an aim of agreeing a high-level framework for a Euro-Atlantic and Eurasian security community. In November, Russia presented a Draft for 'European Security Treaty'. It stated that 'no nation or international organization operating in the Euro-Atlantic region is entitled to strengthen its own security at the cost of other nations or organizations', and that ' $[\mathrm{a}]$ party to the Treaty shall not undertake, participate in or support any actions or activities affecting significantly security of any other Party'. The first part was already enshrined into the OSCE framework, whereas the second was interpreted to give Russia a veto right to any future NATO enlargement. The Draft was not seriously addressed.

As a counter-proposal, Germany launched the 'Meseberg Initiative', but the parties ran into the same problems - Germany tried to bring Russia into table and cooperate with European security issues, but Russia demanded the right to veto any decisions. ${ }^{29}$ Similarly, Russia remained committed to and sought a bigger role for the OSCE where every state has a veto power.

Meanwhile, the post-Soviet space experienced yet another political upheaval, this time in Kyrgyzstan. As the Bakiyev government had failed to address the underlying reasons for the 2005 revolution that had brought it to power, it was brought down by another revolution in 2010. Despite Bakiyev's pleas for help, the CSTO did not intervene. Lukashenko was furious, asking '[w] hat sort of organization is this one, if there is bloodshed in one of our member states and an anti-constitutional coup d'état takes place, and this body keeps silent?' ${ }^{30}$ Notwithstanding this, Russia did not mind the overthrow of the Bakiyev government and the CSTO remained passive.

In conclusion, the 2000s had made Russia suspicious of the Western designs for the states in its sphere of interest. The European security framework remained elusive, and Russia maintained its strict objection against any changes of the geopolitical position of the former SSRs. Furthermore, it believed that such changes could not take place on their own, but were always externally directed. Thus, seemingly internal matters of sovereign states become under this line of reasoning hostile events that require reaction from Russia.

28 Valentina Pop, 'EU Expanding its "Sphere of Influence”, Russia Says' (Eurobserver, 21 March 2009) <https://euobserver.com/foreign/27827> accessed 7 December 2020; Mungo Melvin, Sevastopol's Wars: Crimea from Potemkin to Putin (Osprey Publishing 2017) 611.

29 Philip Remler, 'Negotiations Gone Bad: Russia, Germany, and Crossed Communications' (Carnegie Europe, 21 August 2013) https://carnegieeurope.eu/2013/08/21/negotiation-gone-bad-russia-germany-andcrossed-communications-pub-52712 accessed 7 December 2020.

30 David Trilling, 'Kyrgyzstan Events Helping to Define CSTO Security Alliance' (Eurasianet, 26 April 2010) $<$ https://eurasianet.org/kyrgyzstan-events-helping-to-define-csto-security-alliance> accessed 7 December 2020. 


\section{The Arab Spring, the 'Snow Revolution' and the EaP, 2011-2013}

A series of anti-government demonstrations later known as the 'Arab spring' began in Tunisia in December 2010 and spread quickly in Northern Africa and the Middle East, with varying results. In Libya and Syria, the revolutions developed into civil wars. In March 2011, the UN Security Council established a no-fly zone over most of Libya and authorised the use of 'all necessary means' short of occupation to protect civilians. Russia and China abstained from voting. However, 13 NATO states exceeded the resolution's mandate and sided militarily with the rebels, with some leaders openly stating that President Muammar Gaddafi needed to be replaced. ${ }^{31}$ By October, Gaddafi was brought down, with two long-term consequences: Russia had since then blocked attempts for the UN to intervene in Syria, and categorised the Arab spring as a part of the color revolution pattern. ${ }^{32}$

In December 2011, the greatest demonstration in Russia since the early 1990s, known as the 'Snow Revolution', seemingly confirmed the Kremlin's fears of a color revolution targeting Moscow..$^{33}$ On 15 December 2011, Putin claimed on live television that some of the protesters were paid to participate and that the color revolutions were 'tried and tested schemes for destabilizing society', and in 2012 he wrote '[w]e continue to see new areas of instability and deliberately managed chaos' ${ }^{34}$

While the Kremlin was able to ride out the protests, the timing was awkward as Russia was trying to launch integration projects in the post-Soviet space. In October 2011, eight CIS states signed a free trade agreement, and the following month Russia, Belarus and Kazakhstan announced a plan to establish the Eurasian Economic Union (EEU) by $2015 .{ }^{35}$ The perceived instability was jeopardizing these projects and thus Russia began introducing means to counter the threat caused by the color revolutions. It was discussed in depth in the CSTO conferences in 2011, 2013 and 2014, with calls for a collective response to this threat. In September 2011, the CSTO General Secretary Borduzha presented a plan, according to which an intervention could be authorised by the Council of Heads of State with majority voting. ${ }^{36}$ In 2013, Chief of the General Staff Gerasimov referred to the color revolutions as a form of warfare and that 'a perfectly thriving state can, in a matter of months and even days, be

31 Andrew Quinn, 'Clinton says Gaddafi must go' (Reuters, 28 February 2011) https://www.reuters.com/article/us-libya-usa-clinton-idUSTRE71Q1JA20110228 > accessed 7 December 2020.

32 In March 2011, Lavrov called the Arab spring 'an expected surprise' that is mainly caused by internal problems, unlike the color revolutions, in Vladimir Solovyov, 'Aktual'nyj razgovor' (3 Kanal Television Company, 13 March 2011).

33 Julie Ioffe, 'Snow Revolution' (The New Yorker, 10 December 2011) $<$ https://www.newyorker.com/news/news-desk/snow-revolution> accessed 7 December 2020; Scholars also reflected Kremlin's fears, e.g. Ponamareva ('Russia is the final destination of "color revolutions" since the strategic goal of the West is to immerse Russia in a democratic chaos and to bring it to its final fragmentation'); Varvary Ponamareva, 'Sekreti “cetnih revolyuciy"' (2012) 5(6) Svobodnaya Mysl 38, 39.

34 Vladimir Putin, 'Being Strong: National Security Guarantees for Russia' (Rossiiskaya Gazeta, 20 February 2012) <http://archive.premier.gov.ru/eng/events/news/18185/> accessed 7 December 2020.

35 Madalina S Vicari, 'The Eurasian Economic Union- Approaching the Economic Integration in the PostSoviet Space by EU-Emulated Elements' Papers in Political Economy < https://journals.openedition.org/interventionseconomiques/2823> accessed 7 December 2020.

36 Vladimir Socor, 'Russia Proposes to Codify Intervention Right Via CSTO' (2011) 8(168) Eurasia Daily Monitor. 
transformed into an arena of fierce armed conflict, become a victim of foreign intervention' ${ }^{37}$ This meant it was necessary to seek ways to respond militarily.

Russia internal legislation was changed to deal harsher punishments for unauthorised demonstrations. Moreover, the so-called Foreign Agents Law demanded a special registration for any non-profit organization that engages in political activities and receives even a part of its funding from abroad. ${ }^{38}$

According to its EaP policy, the EU had started negotiating Deep and Comprehensive Free Trade Area (DCFTA) agreements with Armenia, Azerbaijan, Belarus, Georgia, Moldova and Ukraine. Comparably, the 2013 Foreign Policy Concept of Russia listed Ukraine as the 'priority partner within the CIS' and pledged to 'contribute to its participation in extended integration processes'. ${ }^{39}$ The problem was that DCFTA renders the participating state incompatible with any form of association with the EEU. Therefore, when the EU offered a DCFTA to Ukraine in late 2013, Russia felt that its legitimate sphere of interest in the CIS was not recognised and objected strongly.

However, the EU saw this as a bilateral issue between it and Ukraine. In November 2013, European Commission President Barroso commented that the EU will not accept a veto by Russia in relation to its ties with the former SSRs, the era of 'limited sovereignty was over in Europe' and that Russian interference was 'contrary to all principles of international law'. In December, the European Commissioner for Enlargement and European Neighborhood Policy Štefan Füle commented that the EU was willing to make sure the EUUkraine agreement will not harm Russia's economic interest, but 'it will not hold tripartite negotiations on the matter'.

Thus, by the time of the EaP summit in Vilnius in December 2013, Russia and the EU were in a state of ever-increasing confrontation over the political affiliation of the EaP states. In Ukraine, the confrontation became especially severe due to the incompatible and seemingly mutually exclusive views on the political affiliation of Ukraine.

\section{The Destruction of Ukrainian Statehood, 2014}

After the government had suspended the preparations to sign an Association Agreement with the EU, protests started in Ukraine in late 2013. On 6 February 2014, the European Parliament produced a resolution calling for 'the EU and Russia to find ways of making the respective regional integration processes more compatible' and 'opposes Russia's intention to continue to consider the Eastern Partnership region as its sphere of influence'. ${ }^{40}$

The Ukrainian protests gathered momentum, with the Russian attempts to offer profitable trade deals and a 'peace deal' agreed by President Viktor Yanukovych and the

37 Originally in Valery Gerasimov, 'The Value of Science in Foresight' (Military-Industrial Kurier, 27 February 2013), Quoted in Mark Galeotti, 'The "Gerasimov Doctrine" and Russian Non-Linear War' (In Moscow's Shadows, 6 July 2014) <https://inmoscowsshadows.wordpress.com/2014/07/06/the-gerasimov-doctrineand-russian-non-linear-war/> accessed 7 December 2020.

38 International Center for Not-For-Profit Law (ICNL) Law on Foreign Agents (adopted 20 July 2012), art 1.2b $121 \mathrm{FZ}$ regarding 'Amendments to Legislative Acts of the Russian Federation regarding the Regulation of the Activities of Non-profit Organisations Performing the Functions of a Foreign Agent'.

39 Concept of the Foreign Policy of the Russian Federation (adopted on 18 February 2013, entered into force on 18 February 2013) para 48.

40 European Parliament resolution of 6 February 2014 on the EU-Russia summit [2014] (2014/2533(RSP). 
opposition leaders failing to quell them. After Yanukovych decided to flee to Russia, on 22 February 2014, the Ukrainian Parliament voted 328-0 to remove him from the post of the president, and appointed a caretaker President and government until elections could be held. ${ }^{41}$ On 27 February 2014, soldiers later identified as Russian took over public buildings in the Ukrainian Autonomous Republic of Crimea. A new, self-appointed pro-Russian Prime Minister took over the Crimean parliament under murky circumstances. On 16 March 2014, this new government organised a highly criticised referendum on the future status of Crimea without the possibility to vote for the status quo. ${ }^{42}$ The results were allegedly overwhelmingly for joining Russia, which proceeded to incorporate Crimea and Sevastopol to the Russian Federation as two new federal subjects. Russia used its veto in the UN Security Council, but the General Assembly condemned the annexation as contrary to international law in a vote by $100-11$ (58 abstentions). ${ }^{43}$

The destruction of statehood formula that Lavrov had already mentioned in October 2008 was revived. On 4 March 2014, Putin described Ukraine's overthrow of Yanukovych as 'an anti-constitutional takeover [...]. Only constitutional means should be used on the postSoviet space, where political structures are still very fragile, and economies are still weak'. He denied the legitimacy of the new Ukrainian Parliament and President, debating whether the situation was an armed seizure of power or a revolution. In his opinion, if Ukraine had experienced a revolution 'it is hard not to agree with some of our experts who say that a new state is now emerging in this territory. This is just like what happened when the Russian Empire collapsed after the 1917 revolution and a new state emerged. And this would be a new state with which we have signed no binding agreements' ${ }^{44}$ However, the discontinuity of the USSR in respect to the Russian Empire was never recognised in the state practice. ${ }^{45}$

When Ukraine called for consultations regarding the security guarantees it was provided in the 1994 Budapest Memorandum, Russian Foreign Ministry claimed that Russia had not signed the Budapest Memorandum with the then acting government of Ukraine, and was therefore no longer bound by it. As summarised by Pifer, '[u]nder that logic, each and every time a government changes in any state in the world, Russia would have to reconfirm

41 Interfaxukraine, 'Rada removes Yanukovych from office, schedules new elections May 25' (InterfaxUkraine News, 22 February 2014) < https://en.interfax.com.ua/news/general/192030.html> accessed 7 December 2020.

42 Putin admitted the identity of the soldiers in 'Crimea: The Road to Motherland' (Крым. Путь на Родину, 15 March 2015) <https://smotrim.ru/brand/59195> accessed 7 December 2020. The referendum has been condemned by, for example, Council for Europe's European Commission for Democracy through Law: (Opinion on Whether the Decision Taken by the Supreme Council of the Autonomous Republic of Crimea in Ukraine to Organise a Referendum on Becoming a Constituent Territory of the Russian Federation or Restoring Crimea's 1992 Constitution is Compatible with Constitutional Principles (21 March 2014)); Anne Peters, 'Sense and Nonsense of Territorial Referendums in Ukraine, and Why the 16 March Referendum in Crimea Does Not Justify Crimea's Alteration of Territorial Status under International Law' (EJIL: Talk, 16 April 2014); Keir Giles, 'Crimea's Referendum Choices Are No Choice at All' (Chatham House, 20 March 2014).

43 The Agreement between the Russian Federation and the Republic of Crimea on the Accession of the Republic of Crimea in the Russian Federation and on Forming New Constituent Entities within the Russian Federation (18 March 2014); and UNGA Res 68/262 (1 April 2014) UN Doc A/RES/68/262.

44 President of Russia, 'Vladimir Putin answered journalists' questions on the situation in Ukraine' (Kremlin.ru, 4 March 2014) <http://en.kremlin.ru/events/president/news/20366\#sel=19:6:W,19:6:W> accessed 7 December 2020.

45 Peter Hilpold, 'Ukraine, Crimea and New International Law: Balancing International Law with Arguments Drawn for History' (2015) 14(2) Chinese Journal of International Law 237, 257. 
all of its agreements with the new government. International agreements are between states, not between governments'. ${ }^{46}$

The academic community in Russia was also harnessed to promote the destruction of statehood formula. One example of this is a collective 'Statement Concerning the Situation in Ukraine and Legitimacy of Conducting the All-Crimean Referendum on the Status of Crimea on March 16, 2014', put forward by the Association of Lawyers of the Russian Federation (ALRF) on 18 March 2014. In their statement, the ALRF produced the following: 'We propose to proceed from a general principle of law, Ex injuria non oritur jus meaning "law does not arise from injustice" [...]. Removal from office of Ukrainian President proclaimed by the new, self-appointed leaders of Ukraine does not fit in any legal framework' ${ }^{47}$ In his analysis, Merezhko concludes that revolutions are a matter of national, not international, law and do not lead to disappearance to an existing state. Any questions over legitimacy of the new government are under the exclusive jurisdiction of the Ukrainian legal system, not the Russian government or the ALRF. Finally, despite claiming that a new state had emerged, Russia never severed diplomatic relations with Ukraine.

On 18 March 2014, after having signed the law to incorporate Crimea into the Russian Federation, Putin articulated the Russian legal position further in a speech to State Duma deputies and Federation Council members. Referring to the West, Putin said that ' $\mathrm{t}$ ] hey must have really lacked political instinct and common sense not to foresee all the consequences of their actions. Russia found itself in a position it could not retreat from'. On the Ukrainian government, Putin commented that 'there is no legitimate executive authority in Ukraine now, nobody to talk to' and that 'we understand that these actions were aimed against Ukraine and Russia and against Eurasian integration' ${ }^{48}$

In June, Putin stated that '[t]he very concept of national sovereignty is becoming eroded. Undesirable regimes [...] are being destabilized. For that purpose the so-called color revolutions are set in motion [...] they are simply coups, provoked and financed from outside'. In August 2014, Lavrov described the color revolutions as being 'fostered by external forces. Most colour revolutions would not have happened without this external influence'. ${ }^{49}$

In the 2014 Moscow Conference on International Security, Putin described how socioeconomic and political problems were used to replace nationally oriented governments by regimes that are controlled from abroad, and Lavrov lamented how '[a]ttempts to impose

46 Steven Pifer, 'Mr. Lavrov, Russia, and the Budapest Memorandum' (Brooking Institute, 28 January 2016); 'Memorandum on Security Assurances in connection with Ukraine's accession to the Treaty on the NonProliferation of Nuclear Weapons' (United Nations Treaties, 5 December 1994) < https://treaties.un.org/doc/Publication/UNTS/No\%20Volume/52241/Part/I-522410800000280401fbb.pdf $>$ accessed 7 December 2020.

47 Statement of the Association of Lawyers of Russian Federation Concerning the Situation in Ukraine and Legitimacy of Conducting the All-Crimean Referendum on the Status of Crimea on 16.3.2014 (18 March 2014). Quoted in Oleksandr Merezhko, 'Crimea's Annexation by Russia - Contradictions of the New Russian Doctrine of International Law' (2015) 75(1) Zeitschrift für ausländisches öffentliches Recht und Völkerrecht 167, 186.

48 Address by President of the Russian Federation (18 March 2014), found in 'Putin signs treaty to annex Crimea as Ukraine authorizes use of force' (The Gaurdian, 18 March 2014) < https://www.theguardian.com/world/2014/mar/18/ukraine-crisis-putin-plan-crimea-annex-speechrussia-live > accessed 7 December 2020.

49 Putin quote from meeting of the Russian Security Council, 22 June 2014; Lavrov quote in Address at the Youth Education Forum (Seliger, 27 August 2014). 
homemade recipes for internal changes on other nations, without taking into account their own traditions and national characteristics', have a destructive impact. ${ }^{50}$

In conclusion, Russia saw the Ukraine revolution confirming its long held views that color revolutions only target states whose national institutions remain fragile. Thus, Russia became determined to protect itself and its sphere of interest from this phenomenon.

\section{Closing Ranks of the CIS and the CSTO, 2014-2017}

In 2014-2017, the CIS and the CSTO updated their policy documents to counter the color revolutions. Russia also updated its Military Doctrine (December 2014), Concept for Military Cooperation between the CIS Member Countries Through to 2020 (October 2015), National Security Strategy (December 2015), the CSTO Collective Security Strategy for the Period up to 2025 (October 2016), Foreign Policy Concept (December, 2016), and Doctrine of Information Security (December 2016).

In August 2014, Putin explained Russian actions by the logic that while Russia respects Ukraine's sovereign rights to choose its military and economic affiliations, this should not be detrimental to other participants. 'Ukraine is deeply integrated into the CIS economic space [...]. In 2011, a free trade zone agreement was signed within CIS framework, Ukraine took very active stance here' ${ }^{51}$ However, this narrative is incompatible with the destruction of statehood theory - if Ukraine had ceased to exist, it would not have any obligations towards Russia. Nevertheless, under Presidents Poroshenko and Zelensky, Ukraine has boycotted the CIS meetings and announced in April 2018 a complete withdrawal from the organization. Its gradual withdrawal from the CIS agreements continues, with the latest taking place in January 2020.

In September 2014, Lavrov held a speech at the UN General Assembly, calling for harmonization of integration projects so that 'not only NATO and CSTO members but all the countries of the region including Ukraine, Moldova and Georgia can enjoy equal and indivisible security'. After re-advocating the European Security Treaty, he proposed that the General Assembly adopt a declaration on non-interference into domestic affairs of sovereign states and on 'non-recognition of coup d'état as a method of the change of power'. ${ }^{52}$ This would have amounted to de facto legalizing the destruction of statehood formula - outside states could decide on the state's behalf whether its change of power had been legal. The proposal has not been seriously debated since.

50 Putin quote in a speech on 23 May 2014 (translation by the author); Lavrov quote in <https://sputniknews.com/world/20140523190067813-Color-Revolutions-Cause-Apparent-Damage-toInternational/> accessed 7 December 2020.

51 'Speech at the meeting of the Customs Union Heads of State with President of Ukraine and EU representatives' (Kremlin, 26 August 2014)< http://en.kremlin.ru/events/president/transcripts/46494 $>$ accessed 7 December 2020.

52 MFA Russia, 'Address by Russian Foreign Minister Sergey Lavrov to the $69^{\text {th }}$ session of the UN General Assembly, New York, 27 September 2014' (MFA Russia, 27 September 2014) $<$ http://www.mid.ru/en/posledniye_dobavlnenniye//asset_publisher/MCZ7HQuMdqBY/content/id/668972>, accessed 7 December 2020. 
The 2014 Military Doctrine named as a threat 'regimes, which policies threaten the interests of the Russian Federation in the states contiguous with the Russian Federation, including by overthrowing legitimate state administration bodies'. ${ }^{53}$

In February 2015, the Russian Security Council's Patrushev concluded that the 'U.S. administration expects [its recent] anti-Russian measures to decrease quality of life for the population, give rise to mass protests and push Russian citizens to overthrow the current government using the scenario of the "color revolutions". Additionally, the Russian Defense Ministry ordered a major research into color revolutions, with the stated goal of preventing the situations Russia had faced in 1991 and $1993 .{ }^{54}$

While the EEU was finally launched on 1 January 2015, only Armenia, Belarus, Kazakhstan joined in the outset, followed by Kyrgyzstan in August. As Russia had hoped for more participation, its 2015 National Security Strategy blamed the West for aiming to counter Russian-led integration processes, warned that the 'practice of overthrowing legitimate political regimes and provoking intrastate instability and conflicts is becoming increasingly widespread', and listed as one of the main threats external attempts to incite color revolutions. ${ }^{55}$

In October 2015, the CIS updated its Concept for Military Cooperation. The member states pledged to consider 'each other's interests in the implementation of military cooperation' ${ }^{56}$ To understand Russian expansive interpretation over 'each other's interests', one should note Putin's statement on 26 August 2014 of Ukraine's CIS obligations and Article 54 of the 2016 Foreign Policy Concept.

In January 2016, Russia announced its intention to restructure the CSTO, which was accomplished in October of the same year with the 'CSTO Collective Security Strategy for the Period up to 2025' that revised the 2002 CSTO Charter. It listed the color revolutions and attempts to change the constitutional order in the member states as threats, and pledged to 'prevent the support of unconstitutional and unlawful actions in any country leading to the destruction of statehood'. ${ }^{57}$ This was the first official codification of the destruction of statehood concept. While the strategy reaffirmed the possibility to take decisions in a limited format, it did not accept Russian proposals to change the voting procedure from consensus to majority voting.

After these changes, Russia has a wide array of means to intervene in the near abroad. It could act under a government's invitation, a defense agreement, or the new CSTO strategy if it were to categorise the situation as an attempt to 'destroy the statehood'. Furthermore,

53 Military Doctrine of the Russian Federation (adopted on 25 December 2014, entered into force on 25 December 2014) art 12(m).

54 'US is trying to dismember Russia, says Putin adviser' (Wall Street Journal)

$<$ https://www.wsj.com/articles/u-s-is-trying-to-dismember-russia-says-putin-adviser-1423667319>; 'Putin vows to prevent 'color revolutions' for Russia and its Eurasian allies' (Russia Today, 12 April 2017)

$<$ https://www.sott.net/article/347907-Putin-vows-to-prevent-color-revolutions-for-Russia-and-its-

Eurasian-allies>, accessed on 7 December 2020.

55 Russian National Security Strategy (adopted on 31 December 2015, entered into force on 12 January, 2016) arts 17,18 and 43 .

56 Concept for Military Cooperation between the CIS Member Countries Through to 2020 (16 October 2015) II. Basic Principles, Goals and Objectives of Military Cooperation.

57 CSTO Collective Security Strategy for the Period up to 2025 (adopted on14 October 2016, entered into force on 14 October 2016) arts 3, 3.1 and 6.1. Translation by the author. 
Russia gained leverage over the CIS with increased possibilities to interpret their actions to be against its interests.

In 2016, a revised Foreign Policy Concept was published. It announced that '[w]hile respecting the right of its partners within CIS to establish relations with other international actors, Russia expects CIS member states to fully implement their obligations within the integration structures that include Russia, as well as further promote integration and mutually beneficial cooperation in CIS space'. ${ }^{58}$

To summarize, with these measures Russia has created several different legal or treatybased frameworks with which it can justify interference into what are otherwise internal affairs of sovereign states within its self-proclaimed sphere of interest.

\section{Later Developments}

In June 2017, a group of Russian legal scholars published a collective opinion on the Crimean Referendum. According to it, the Ukrainian Constitution had lost its effect, and the Crimean referendum was legitimate because of the "unconstitutional coup d'état carried out with foreign participation'. Furthermore, the 'new government committed a felony and its actions had no legal power for the Russian Federation' and the Venice Commission's condemning Opinion on the Crimean Referendum 'seems to be unconvincing because the constitutional norms on the functioning of the Ukrainian government that functioned before the coup d'état were ruined'. ${ }^{59}$ This is another demonstration how Russia sees itself having a right to judge on what are constitutional or unconstitutional acts in a foreign state.

In April 2018, another pro-Russian leader was overthrown in Armenia. As the West did not play any demonstrable role, Russia avoided a tough response. Although the new Prime Minister Nikol Pashinyan pledged continuity in the Armenian-Russian relationship, Armenia could still pose a problem as an example of a non-violent regime change. In July 2018, Lavrov commented that 'the events happening there inevitably worry us, including from the point of view of normal operations of the CIS of which Armenia is a member state'. In other words, Russia tries to make itself a direct subject of what is clearly an internal matter through Armenia's CIS commitments.

Finally, on 30 May 2018 a Russian Federation Council's Commission on Protecting State Sovereignty and Preventing Foreign Interference concluded that the West actively participated in destabilizing Arab states prior to the Arab Spring and had tried the same in Russia in 2011-2012. ${ }^{60}$

\section{Conclusions}

Russia remains committed to countering color revolutions and allocates significant resources for this task. It has listed the color revolutions as main threats in the 2011 Draft Convention on International Information Security and in the 2015 National Security Strategy, and has

58 Foreign Policy Concept of the Russian Federation (adopted on 30 November 2016, entered into force on 30 November 2016) arts 52, 54 and 55. These statements, while already present in the 2013 Concept, should be read in a different light after 2014.

59 'Concerning Legitimacy of the Crimean Referendum, 2014' (Government of Crimea, 21 June 2017) < https://rk.gov.ru/file/dok en.pdf $>$ accessed 7 December 2020.

60 Special Report on the Results of the Presidential Elections in the Russian Federation (2018) from the Point of View to Russian Electoral Sovereignty (30 May 2018) 8; Translation by the author. 
changed the CSTO Treaty so it can more easily intervene in the case of a revolution. Finally, the Russian military has listed color revolutions as a form of warfare and has been working on ways to counter them. ${ }^{61}$

While the CIS commitments are vaguer, Russia has since 1995 made a main task of its foreign policy to ensure that the member states abide by friendly policies towards Russia, and has since 2013 changed its Foreign Policy Concept so that it may categorise any revolutionary development to be its concern through the target state's CIS commitments.

Russia is signaling that it is taking this threat very seriously. Eventually, it does not matter whether the Kremlin believes its own rhetoric of the color revolutions being a political tool of the West or if it is just using this as an excuse to intervene in its self-proclaimed sphere of interest. The result remains the same: Russia is currently unable to accept any kind of unconstitutional change of power in the post-Soviet space, as proven yet again with its rhetoric towards the upheaval in Minsk after the August 2020 elections.

In conclusion, the concepts of the destruction of statehood and the color revolutions are indistinguishable from the concept of 'near abroad'. As Russian concerns are in reality about the target state's Western alignment, its reaction can be predicted by evaluating the chances of the target state to change its political affiliation. For example, despite labelling them as color revolutions, Moscow did not intervene in Kyrgyzstan in 2005 and 2010, since there was no risk for Kyrgyzstan defecting to the Western camp. Indeed, in 2020, Kyrgyzstan is a member state of the CIS, the CSTO and the EEU. Under the Russian narrative, the main competition is over influence in Georgia, Moldova and Ukraine, followed by Armenia, Azerbaijan and Belarus. Russia has a stronger 'claim' to these states due to their CIS and CSTO commitments, and historical and cultural ties.

The new developments in the Russian international law doctrine since 2014 are worrying. Russia has developed legal tools to counter color revolutions before they bring about a reversal of the target state's geopolitical direction. If the revolution nevertheless succeeds, this is categorised as the 'destruction of statehood' that extinguishes the target state. However, international law does not accept the concept of 'un-recognizing' a state because of its change of a regime and the 'precedent' for this - the USSR in 1917 - is not recognised in state practice. The notion that a foreign state could establish the legitimacy of another state's government is a clear interference into its internal affairs. It is this interpretation of state sovereignty where the main political difference between Russia and the West lies. The West maintains that any possible coups or revolutions are within the internal affairs of that state alone, whereas Russia asserts that the coups or revolutions would not have taken place without the West's illegal interference into the target state's internal affairs. This fundamental disagreement drives the relationship between Russia and the West into confrontation, without any consequential dialogue on the issue taking place.

Therewith, what was first envisioned as the indivisible European security order has transformed into two competing schools of thought on state sovereignty. While Russia has been unable to convince the West or the wider international community to accept its new interpretations on sovereignty, it has been able to consolidate a mutual understanding of them in the CSTO and the CIS. Thus, while some post-Soviet state leaders have gained assurances that they cannot be removed from power via unconstitutional means, they might be slowly

61 'Russia's Defense Ministry Takes “Color Revolutions” in Their Sights' (Covert Geopolitics, 24 June 2015) <https://sputniknews.com/russia/201506241023776766/> accessed 7 December 2020. 
243 GroJIL 8(2) (2021), 228-243

relinquishing their sovereignty in exchange. For example, it certainly cannot be excluded that if the current regime in Belarus would have to flee the country, Russia would not choose to categorise this as a color revolution and intervene militarily, even without a formal request. This endangers the independence of the post-Soviet states and is a worrying sign of the Russian policy towards the near abroad since 2014. 